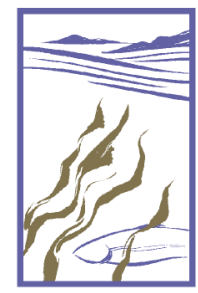

NORTHWEST STRAITS

marine conservation initiative

\title{
Marine Habitat Recovery of Five Derelict Fishing Gear Removal Sites in Puget Sound, Washington
}

PREPARED FOR:

NORTHWEST STRAITS INITIATIVE

PREPARED BY:

JEFF JUNE

KYLE ANTONELIS

NATURAL Resources Consultants, INC.

February 11, 2009 


\section{Acknowledgements}

This research was funded by grants to the Northwest Straits Marine Conservation Foundation from the Puget Sound Conservation Fund, the National Fish and Wildlife Foundation, and the United States Fish and Wildlife Service Coastal and Recovery Programs. 


\section{Executive Summary}

Derelict fishing gear kills thousands of marine animals in Puget Sound every year. It also destroys and degrades marine habitat by accumulating sediment, scouring, impeding plant and sessile animal growth and blocking access to habitats used for feeding and escaping predators. This study had three objectives. First was to document impacts of derelict fishing gear on marine habitats. Second was to monitor the recovery of these habitats after derelict fishing gear was removed. Third was to monitor sites for newly lost fishing gear to determine reaccumulation rates at these sites.

Five derelict fishing gear removal sites were selected: four derelict gillnet sites and one derelict crab pot site. All net sites represented slightly different habitat types and the crab pot site was in an eelgrass bed. At the four derelict net sites, fishing gear was removed during the summer of 2007 and the affected areas delineated with weighted yellow ropes. The sites were monitored before and immediately after derelict fishing gear was removed, and again after approximately six months and one year. The derelict crab pot was removed in June 2008 and monitored after four and eight months.

Monitoring was conducted by divers using surface supplied air. Divers were equipped with a two-way radio and provided qualitative descriptions of the area affected by the derelict gear and control areas adjacent to the affected areas. Descriptions included observations of presence or absence of derelict fishing gear, use of the site by fish and other mobile species and occurrence of vegetation and sessile animals. Divers also took video footage of each site and adjacent control areas. This video footage was analyzed to determine relative abundance of plants and animals in each removal site and control area and to assess overall removal site recovery compared to the control areas.

Relative abundance was measured at each net removal site and each adjacent control site for four species groups: kelp/seaweed/hydroid, sessile invertebrates, mobile invertebrates, and fish. There was a $41 \%$ difference in the relative abundance at all four net sites compared to control sites immediately after gear removal, indicating that the gear and its removal resulted in reduced species abundance in the gear affected marine habitat. After six months (midwinter), there was a $31 \%$ difference in relative abundance at the four net sites compared to the control sites. Most of this difference occurred in the $\mathrm{kelp} / \mathrm{seaweed} / \mathrm{hydroid}$ and sessile invertebrates groups. After one year, the difference in relative abundance between the removal sites and control areas decreased to $6 \%$. This indicates that abundance of marine species using the net affected habitat can be restored to $94 \%$ in about one year after derelict fishing net removal, or one growing season in the case of the kelp/seaweed/hydroid group..

After removal of the derelict crab pot, divers noted no eelgrass in the pot footprint or in a fifteen foot square area directly behind the pot where a one foot deep hole had been scoured out due to currents moving around the pot. The control area adjacent to the pots had a high density of eelgrass. Four months after pot removal, divers noted a $30 \%$ recovery of eelgrass in the area affected by the pot. The eelgrass was found to be 
spreading from the adjacent area. The scour hole had filled in. No further increase in eelgrass density was observed after eight months over winter.

Further review of the video footage taken during the separate monitoring dives was conducted to see whether the control and net affected areas could be differentiated throughout the study. Ninety-four video clips totaling 59 minutes were reviewed by a biologist. The reviewer was unaware of whether the video was from the control area or the net affected area. He was able to distinguish the net affected area from the control area immediately after removal on average $88 \%$ of the time. After six months, he was able to distinguish the difference $92 \%$ of the time. After one year, he was able to distinguish the difference only $51 \%$ of the time, indicating that the areas looked too similar to reliably tell them apart.

Divers found no new derelict fishing gear at any of the removal sites during the study.

This study showed that marine habitat service functions are negatively affected by derelict fishing gear. It showed that natural ocean processes succeed in restoring these service functions within a single growing season after derelict fishing gear removal for areas dominated by kelp. Eelgrass beds take longer to recover, but can improve by $30 \%$ in less than a year. 


\section{Introduction}

Abandoned, lost and discarded fishing gear can present safety, liability, nuisance and environmental impact issues in marine waters. Identification, location and safe removal of derelict fishing gear can reduce these impacts. The Northwest Straits Initiative (NWSI) teamed with the National Oceanic and Atmospheric Administration (NOAA) and the Washington Department of Fish and Wildlife (WDFW) to address the issue of derelict fishing gear in Puget Sound and the Strait of Juan de Fuca. The result of this project is a comprehensive program to safely remove derelict fishing gear from the marine environment in an environmentally acceptable manner. WDFW composed guidelines for derelict fishing gear removal in Washington marine waters based on the NOAA/NWSC project.

These guidelines have been used in derelict fishing gear removal on Puget Sound waters since 2002. During this time over 1,000 derelict nets and 1,707 crab pots have been removed covering approximately 240 acres of seabed thereby preventing further entanglement and mortality of marine mammals, seabirds, fish and invertebrates. However, the overall impact of derelict fishing gear goes beyond impacts to animal life. Evidence shows that derelict fishing gear also negatively impacts marine habitat service functions such as denial of access to habitats, sediment accumulation, scouring, blocking of eelgrass growth, etc.

The study had three objectives. First was to observe and document the impacts of derelict nets and crab pots on different marine habitats. The second was to monitor the recovery of these marine habitats immediately after derelict fishing gear removal, at six months and after one year. The third objective was to monitor the long-term (LTM) monitoring sites for any newly deposited derelict fishing gear to estimate deposition rates. Gaining this knowledge significantly increases our understanding of the immediate and long-term positive results of habitat restoration from derelict fishing gear removal.

\section{$\underline{\text { Methods }}$}

Four derelict nets (salmon gillnets) and one derelict Dungeness crab, Cancer magister, pot were chosen based on typical marine habitats were derelict fishing gear is found in Puget Sound (Table 1 and Figure 1). The derelict nets impacted high relief rocky substrate and boulder/sand habitat. The derelict crab pot was located in eelgrass, Zosteras sp., where tidal currents had eroded a large three-foot by five-foot hole approximately one foot deep behind the pot that was devoid of eelgrass. Divers delineated the affected area around each derelict gear item with a weighted yellow rope, recorded underwater video of the net affected area and surrounding unaffected area and reported their observations of habitat impacts and the relative abundance of plant and animals species. The derelict fishing gear was then removed and video and diver observations of the affected area recorded. Identical monitoring occurred approximately six months and one year after net removal and four months and eight months after pot removal (Table 2). 
Table 1: Derelict gear chosen for habitat monitoring, locations, minimum and maximum depth (feet), type of habitat and length and width (feet).

\begin{tabular}{|l|l|l|l|l|l|l|l|l|l|}
\hline $\begin{array}{l}\text { GEAR } \\
\text { ID }\end{array}$ & $\begin{array}{l}\text { GEAR } \\
\text { TYPE }\end{array}$ & LOCATION & LAT(N) & LONG(W) & $\begin{array}{l}\text { DEPTH } \\
\text { MIN(ft) }\end{array}$ & $\begin{array}{l}\text { DEPTH } \\
\text { MAX(ft) }\end{array}$ & $\begin{array}{c}\text { HABITAT } \\
\text { TYPE }\end{array}$ & $\begin{array}{l}\text { LENGTH } \\
(\mathrm{ft})\end{array}$ & $\begin{array}{l}\text { WIDTH } \\
(\mathrm{ft})\end{array}$ \\
\hline LTM\#1 & Gillnet & $\begin{array}{l}\text { Lopez } \\
\text { Island }\end{array}$ & $\begin{array}{l}4824.99 \\
9\end{array}$ & $\begin{array}{l}12250.53 \\
5\end{array}$ & 52 & 77 & $\begin{array}{l}\text { Moderate } \\
\text { relief, rocky } \\
\text { reef }\end{array}$ & 1000 & 60 \\
\hline LTM\#2 & Gillnet & $\begin{array}{l}\text { Foulweath } \\
\text { er Bluff }\end{array}$ & $\begin{array}{l}4756.76 \\
9\end{array}$ & $\begin{array}{l}12237.00 \\
7\end{array}$ & 41 & 45 & $\begin{array}{l}\text { Low relief, } \\
\text { rock, gravel } \\
\text { and kelp }\end{array}$ & 500 & 80 \\
\hline LTM\#3 & Gillnet & $\begin{array}{l}\text { San Juan } \\
\text { Is., Eagle } \\
\text { Point }\end{array}$ & $\begin{array}{l}4827.45 \\
2\end{array}$ & $\begin{array}{l}12302.16 \\
5\end{array}$ & 57 & 85 & $\begin{array}{l}\text { High relief, } \\
\text { rocky reef face } \\
\text { near kelp } \\
\text { forest }\end{array}$ & 300 & 50 \\
\hline LTM\#4 & Gillnet & $\begin{array}{l}\text { San Juan } \\
\text { Is., Cattle } \\
\text { Point }\end{array}$ & $\begin{array}{l}4826.97 \\
1\end{array}$ & $\begin{array}{l}12300.28 \\
2\end{array}$ & 41 & 90 & $\begin{array}{l}\text { Large boulders } \\
\text { on sand slope }\end{array}$ & 1000 & 80 \\
\hline LTM\#5 & $\begin{array}{l}\text { Crab } \\
\text { Pot }\end{array}$ & $\begin{array}{l}\text { Port } \\
\text { Gardner, } \\
\text { Gedney Is. }\end{array}$ & $\begin{array}{l}4800.65 \\
1\end{array}$ & $\begin{array}{l}12218.46 \\
7\end{array}$ & 23 & 23 & $\begin{array}{l}\text { Sand, mud, } \\
\text { eelgrass }\end{array}$ & NA & NA \\
\hline
\end{tabular}

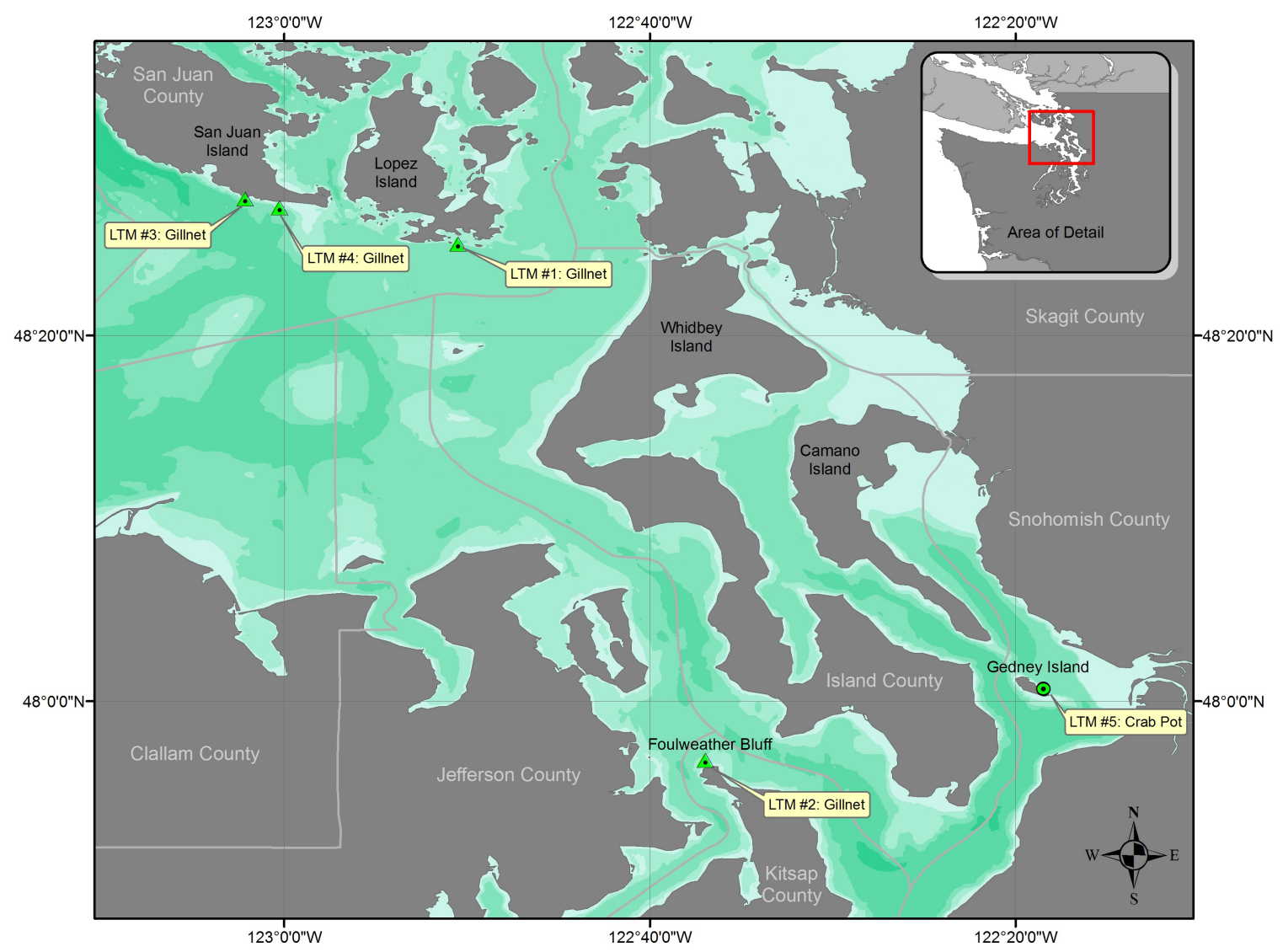

Figure 1: The location the five long-term derelict fishing gear monitoring areas in Puget Sound the San Juan Island.

Marine Habitat Recovery of Five Derelict Fishing Gear Removal Sites in Puget Sound, WA

February 11, 2009

Page 6 
Table 2: $\quad$ Survey intervals for the chosen habitat locations.

\begin{tabular}{|c|c|c|c|c|}
\hline \multirow[t]{3}{*}{ LTM\#1 } & Survey Date & $\begin{array}{c}6 / 21 / 2007 \\
\text { Net removal and } \\
\text { initial survey }\end{array}$ & $\begin{array}{c}1 / 15 / 2008 \\
\approx 6 \text { month survey }\end{array}$ & $\begin{array}{c}9 / 17 / 2008 \\
\approx 1 \text { year survey }\end{array}$ \\
\hline & $\begin{array}{l}\text { Elapsed time since } \\
\text { net removal (days) }\end{array}$ & & 208 & 454 \\
\hline & $\begin{array}{l}\text { Elapsed time since } 6 \\
\text { month survey (days) }\end{array}$ & & & 246 \\
\hline \multirow[t]{3}{*}{ LTM\#2 } & Survey Date & $\begin{array}{c}8 / 7 / 2007 \\
\text { Net removal and } \\
\text { initial survey }\end{array}$ & $\begin{array}{c}1 / 19 / 2008 \\
\approx 6 \text { month survey }\end{array}$ & $\begin{array}{c}9 / 18 / 2008 \\
\approx 1 \text { year survey }\end{array}$ \\
\hline & $\begin{array}{l}\text { Elapsed time since } \\
\text { net removal (days) }\end{array}$ & & 165 & 408 \\
\hline & $\begin{array}{l}\text { Elapsed time since } 6 \\
\text { month survey (days) }\end{array}$ & & & 243 \\
\hline \multirow[t]{3}{*}{ LTM\#3 } & Survey Date & $\begin{array}{c}8 / 23 / 2007 \\
\text { Net removal and } \\
\text { initial survey }\end{array}$ & $\begin{array}{c}2 / 14 / 2008 \\
\approx 6 \text { month survey }\end{array}$ & $\begin{array}{c}9 / 17 / 2008 \\
\approx 1 \text { year survey }\end{array}$ \\
\hline & $\begin{array}{l}\text { Elapsed time since } \\
\text { net removal (days) }\end{array}$ & & 175 & 391 \\
\hline & $\begin{array}{l}\text { Elapsed time since } 6 \\
\text { month survey (days) }\end{array}$ & & & 216 \\
\hline \multirow[t]{3}{*}{ LTM\#4 } & Survey Date & $\begin{array}{c}8 / 23 / 2007 \\
\text { Net removal and } \\
\text { initial survey }\end{array}$ & $\begin{array}{c}2 / 14 / 2008 \\
\approx 6 \text { month survey }\end{array}$ & $\begin{array}{c}9 / 17 / 2008 \\
\approx 1 \text { year survey }\end{array}$ \\
\hline & $\begin{array}{l}\text { Elapsed time since } \\
\text { net removal (days) }\end{array}$ & & 175 & 391 \\
\hline & $\begin{array}{l}\text { Elapsed time since } 6 \\
\text { month survey (days) }\end{array}$ & & & 216 \\
\hline \multirow[t]{3}{*}{ LTM\# 5} & Survey Date & $\begin{array}{c}6 / 25 / 2008 \\
\text { Pot removal and } \\
\text { initial survey }\end{array}$ & $\begin{array}{c}10 / 11 / 2008 \\
\approx 4 \text { month survey }\end{array}$ & $\begin{array}{c}2 / 21 / 2009 \\
\approx 8 \text { month survey }\end{array}$ \\
\hline & $\begin{array}{l}\text { Elapsed time since } \\
\text { pot removal (days) }\end{array}$ & & 138 & 241 \\
\hline & $\begin{array}{l}\text { Elapsed time since } 4 \\
\text { month survey (days) }\end{array}$ & & & 103 \\
\hline
\end{tabular}

Three methods of qualitative habitat recovery assessment were conducted: (1) diver observations of visual habitat improvement and relative species abundance during each monitoring period, (2) review of underwater video footage and scoring indices of relative abundance of species groups between the net affected and unaffected "control" areas and (3) review of random video clips

\section{Diver Reports}

An onboard biologist documented diver observations during pre- and post-gear removal monitoring dives. Divers described the condition of the derelict gear, impacts on the marine habitat and relative abundance of plants and animals within the net affected area in the adjacent unaffected "control" areas. Divers then delineated the area affected by the derelict gear with a weighted yellow rope and the derelict gear was removed. Immediately after removal divers again monitored both the gear affected and unaffected areas and reported their observations. During subsequent monitoring dives ( six months and one year post-removal for net sites and four and eight months for the pot site) divers indicated whether or not the pot affected area could be readily distinguished visually from the surrounding unaffected control habitat. Divers reported the relative size, Marine Habitat Recovery of Five Derelict Fishing Gear Removal Sites in Puget Sound, WA February 11, 2009

Page 7 
abundance and species diversity of marine plants, sessile invertebrates, mobile invertebrates and fish and took underwater video within the gear affected area and in adjacent unaffected habitat at each monitoring location. Divers attempted to cover as much of the derelict fishing gear affected area as possible and obtain a representative sample of the unaffected area during each sampling period. Divers inspected the overall removal area for any newly deposited derelict fishing gear on each monitoring dive.

\section{Relative Abundance of Plants and Animals}

Underwater video of the affected and unaffected habitat at each location and monitoring period was reviewed and the relative abundance assigned ( $1=$ absent or rare, $2=$ moderately abundant and $3=$ =abundant) of four general species groups, (1) kelp/seaweed/hydroids, (2) sessile invertebrates, (3) mobile invertebrates and (4) fish. Abundance scores were averaged over all samples reviewed for each species group and across species groups for a total average plant and animal index value by affected and unaffected area and sampling period. Average abundance index scores were compared between affected and unaffected areas and over sampling periods for each of the four habitat monitoring areas and across all habitat areas. Changes in the difference between affected and unaffected habitat area abundance scores over time provided a qualitative measure of habitat recovery or lack of recovery after gear removal.

\section{Affected Versus Unaffected Area Video Review}

Random 30 to 90 second video clips from each monitoring site were reviewed by a biologist with no prior knowledge of whether the clips were from net affected or unaffected areas. The biologist selected the location of each video clip as either from the net affected or unaffected control area. It was assumed that if sufficient differences existed in the general appearance and species abundance between the affected area and the unaffected area the biologist should be capable of discerning the correct identity $(\mathrm{C}=$ unaffected or control and $\mathrm{NA}=$ net affected) of the area in each video clip. If affected habitats recovered over the study period, the differences in the general appearance between the affected areas and the unaffected areas should diminish and it would be more difficult for the biologist to correctly guess the origin of the location in the video clips.

\section{$\underline{\text { Results }}$}

\section{Diver Reports}

Divers reported dramatic differences in the derelict gear affected habitat compared with the surrounding unaffected or control areas immediately after gear removal in all areas studied. Certainly some of the habitat impacts were due to the actual physical removal of the derelict net. Plants and sessile animals grow on and nearby the derelict gear and are removed and/or dislodged during derelict gear recovery operations. However, divers routinely report that derelict nets tend to move with the tide and current, effectively sweeping plants and sessile animals from the seabed. In some cases, derelict nets may be 
secured to the bottom at one end but sweep in an arc 40 to 60 feet along the seabed on the other end, entangling animals encountered and preventing sessile plants and animals from attaching to the seabed.

At each of the four derelict net monitoring sites divers reported that the net affected area was very obvious from the surrounding unaffected habitat immediately after net removal. The main difference in the affected area was the lack of attached kelp, sessile animals and the presence of essentially bare rock, gravel and sand under where the derelict net had been located. Fish densities tended to be somewhat higher in the net affected areas than in the adjacent unaffected control areas immediately after gear removal, probably due to a feeding attraction on dislodged prey items.

At the derelict crab pot site, a three-foot wide by five-foot long scour hole approximately one foot deep had developed behind the derelict pot and was devoid of eelgrass as was the area immediately under the crab pot. Similar scour areas are fairly frequently observed next to derelict crab pots in Puget Sound and may be caused by tidal currents creating a vortex to one side of the pot eroding out the seabed. Once the derelict pot was removed, the divers reported an obvious area with almost no eelgrass at the pot location and in the depression behind the pot compared with abundant eelgrass in the adjacent area not affected by the derelict pot.

In January and February of 2008, approximately six months after the initial net removals, divers reported little or no habitat recovery at each of the four net removal sites. The derelict gear affected areas remained very obvious and visually discernable from surrounding unaffected habitat. A somewhat greater abundance of sea cucumbers, Parastichopus californicus, green sea urchins, Strongylocentrotus droebachiensis, and smooth pink scallops, Chlamys rubida, were observed in the net affected areas at LTM\#1 and LTM\#3 but generally plant and animal densities in the net affected areas remained low compared with unaffected areas.

At LTM \#1 on Lopez Island the six month post-gear removal monitoring dive was conducted in January 2008, 208 days after net removal. Divers reported a greater abundance of sea cucumbers (Parastichopus californicus), green sea urchins (Strongylocentrotus droebachiensis) and smooth pink scallops (Chlamys rubida) within the net affected area than in the surrounding unaffected area. However, divers reported that the net affected area remained obviously different from the unaffected area mainly due to a lack of kelp, encrusting algae, sponges or corals and somewhat fewer sessile invertebrates and fish than in the surrounding unaffected.

At LTM \#2 off Foulweather Bluff the six-month (165 days) monitoring dive was conducted in January 2008. Divers reported little, if any, habitat recovery in the net affected area and it remained obviously different from the unaffected area mainly due to a lack of kelp and sessile animals.

At LTM\#3 off Eagle Point, San Juan Island, the six-month (175 days) monitoring dive was conducted in early February 2008. Divers reported no indication of habitat recovery 
mainly due to a lack of kelp and sessile animals but the abundance of sea cucumbers and green sea urchins appeared to be somewhat higher in the net affected area than in the unaffected control area, although the lack of kelp may have made the animals easier to see than in the unaffected area that had abundance kelp growth. The net affected area remained obviously different than the adjacent unaffected control area.

At LTM\#4 off Cattle Point, San Juan Island, the six-month (175 days) monitoring dive was also conducted in early February 2008. Divers reported no indication of habitat recovery, again mainly due to a lack of kelp and sessile animals. The net affected area remained obviously different than the adjacent unaffected control area.

At LTM\#5, the derelict crab pot site off Gedney Island, divers conducted a monitoring dive approximately 4 months (138 days) after the derelict pot was removed. Divers reported the one-foot deep scour area behind the pot location had completely filled in with a mixture of sand and mud substrate and was level with the surrounding seabed. The location of the removed crab pot and the scour area was still obvious, due mainly to a lower density of eelgrass within the pot affected area. However, divers reported that new eelgrass shoots were present within the pot affected area along the edge of the unaffected area. Divers observed that new eelgrass plants were mainly the result of eelgrass plants growing from the roots of established plants in the unaffected control area that were spreading into the edges of the pot affected area. The divers estimated the size of the pot affected area had decreased by one foot in width (from three feet to two feet) along the five foot length of pot scour area, a partial restoration of $30 \%$ of the habitat.

Approximately one year (454 days) after net removal in September 2008, divers monitoring LTM\#1 reported significant habitat recovery in the net affected area. Divers reported that the net affected area was obvious from the unaffected control area but mainly due to the reduced height of the ribbon kelp, Alaria marginata, within the net affected area. Densities of ribbon kelp, encrusting animals, sessile and mobile invertebrates and fish were similar in the net affected and unaffected areas.

At LTM\#2 off Foulweather the one-year (408 days) monitoring dive was conducted in September 2008. Divers reported extensive patches of ribbon kelp and some bull kelp, Nereocystis luetkeana, in the net affected area. The density of bull kelp was lower in the net affected area but the density of ribbon kelp was similar to the adjacent unaffected control area. The reduced height of the ribbon kelp was obvious in the net affected area but the relative abundances of sessile and mobile invertebrates and fish were similar. Divers were capable of distinguishing the net affected area from the unaffected control area.

At LTM\#3 off Eagle Point on San Juan Island, the one-year (391 days) monitoring dive was conducted in September 2008 and divers reported that it was extremely difficult to distinguish the net affected area from the unaffected control area. One side of the yellow marker rope was missing and the divers were unable to determine the boundary between the net affected habitat and the unaffected control habitat. Divers reported that the densities and sizes of both ribbon and bull kelp were similar in the net affected and 
control areas. The bare rock that had been exposed immediately after net removal and was still evident at the six-month sampling period was completely encrusted in algae and small sponges. Sessile invertebrates, primarily anemones, Metridium sp., Puget Sound king crab, Lopholithodes mandtii, and juvenile rockfish, Sebastes sp., were observed to be equally abundant in both the net affected and unaffected control areas.

At LTM\#4 off Cattle Pass, San Juan Island the one-year (391 days) monitoring dive was conducted in September 2008. Divers reported the net affected area remained somewhat discernable from the control area mainly due to the lower height of the ribbon kelp in the net affected area. Divers noted that the densities of ribbon kelp attached to the seabed were similar in both areas, previously bare rock in the net effected area was essentially covered by encrusting organisms and green sea urchins, Strongylocentrotus droebachiensis, and sea cucumbers were equally abundant in both areas. Divers noted that fish, primarily kelp greenling, Hexagrammos decagrammus, and juvenile rockfish, appeared to be more abundant in the net affected area than in the unaffected control area.

LTM\#5, the derelict pot site, was monitored on February 21, 2009, approximately eight months (241 days) after the pot removal. Divers reported no discernable change in eelgrass density compared with the monitoring dive four months earlier. Post-pot removal habitat recovery appeared to remain at about $30 \%$.

\section{Relative Abundance of Plants and Animals}

A total of 125 video clips with a total length of 86 minutes and 13 seconds were reviewed from the four net affected and adjacent control areas over the three sampling periods.

Indices of relative abundance ( $1=$ absent or rare, $2=$ moderately abundant and $3=$ abundant) of four habitat parameters (kelp/seaweed/hydroids, sessile invertebrates, mobile invertebrates and fish) were scored in both the net affected and control areas immediately after net removal, after six months and after one year of net removal. Although subjective, the data suggests that the abundance of plants and animals was generally lower in the net affected area than in the unaffected control area immediately after net removal and six months after net removal but abundance increased in the net affected area after one year to nearly equal to the unaffected control area indicating 85 to $97 \%$ habitat recovery.

At each of the four net affected habitat monitoring sites, the relative abundances of the four species groups were lower in the net affected area than in the unaffected area immediately after net removal (Table 3). Only fish were more abundant in the net affected area than the control area at LTM\#1 immediately after net removal and they were probably attracted by the availability of prey items dislodged during the net removal operations. The average abundance index value for the net affected areas at the four monitoring sites was 1.34 (range 1.21 to 1.60 ) compared with 2.26 (range 2.06 to 2.60) for the unaffected areas. Differences in relative abundances between the net affected areas and the unaffected areas were larger for the kelp/seaweed/hydroid and sessile invertebrate groups than for the mobile invertebrate and fish groups. Overall average percent differences in relative abundant among the four species groups between net 
affected areas and control areas immediately after net removal ranged from $38 \%$ at LTM\#3 to $46 \%$ at LTM\#2 and averaged $41 \%$ over all four monitoring sites.

Table 3: Average relative abundance index scores for four groups of plants and animals in net affected and adjacent control areas at four long-term habitat monitor sites immediately after derelict net removal, six months and one year. (Abundance indices are $1=$ absent of rare, $2=$ moderately abundant and $3=$ abundant).

\begin{tabular}{|c|c|c|c|c|c|c|c|c|c|c|}
\hline \multirow[b]{2}{*}{ LTM } & \multirow[b]{2}{*}{ Period } & \multirow[b]{2}{*}{ Category } & \multirow[b]{2}{*}{$\begin{array}{c}\# \\
\text { Samples } \\
\end{array}$} & \multirow[b]{2}{*}{$\begin{array}{c}\text { Total Time } \\
(\mathrm{sec})\end{array}$} & \multicolumn{6}{|c|}{ Average Score } \\
\hline & & & & & \begin{tabular}{|c}
$\begin{array}{c}\text { Kelp/Seaweed/ } \\
\text { Hydroid }\end{array}$ \\
\end{tabular} & $\begin{array}{l}\text { Sessile } \\
\text { Inverts } \\
\end{array}$ & $\begin{array}{l}\text { Mobile } \\
\text { Inverts }\end{array}$ & Fish & Total & $\%$ Diff \\
\hline \multirow[t]{9}{*}{1} & Immediate & Control & 4 & 195 & 2.50 & 2.25 & 2.25 & 1.25 & 2.06 & \\
\hline & Post-Removal & Net Area & 4 & 167 & 1.25 & 1.00 & 1.25 & 1.50 & 1.25 & \\
\hline & & Difference & & & 1.25 & 1.25 & 1.00 & -0.25 & 0.81 & $39 \%$ \\
\hline & 6-Month & Control & 3 & 107 & 1.67 & 2.00 & 2.67 & 1.67 & 2.00 & \\
\hline & Post-Removal & Net Area & 5 & 121 & 1.00 & 1.20 & 1.60 & 1.40 & 1.30 & \\
\hline & & Difference & & & 0.67 & 0.80 & 1.07 & 0.27 & 0.70 & $35 \%$ \\
\hline & 1-Year & Control & 6 & 211 & 2.67 & 2.67 & 2.50 & 2.17 & 2.50 & \\
\hline & Post-Removal & Net Area & 5 & 174 & 2.40 & 2.60 & 2.00 & 1.60 & 2.15 & \\
\hline & & Difference & & & 0.27 & 0.07 & 0.50 & 0.57 & 0.35 & $14 \%$ \\
\hline \multirow[t]{9}{*}{2} & Immediate & Control & 7 & 354 & 2.57 & 2.86 & 2.14 & 1.43 & 2.25 & \\
\hline & Post-Removal & Net Area & 6 & 284 & 1.17 & 1.00 & 1.50 & 1.17 & 1.21 & \\
\hline & & Difference & & & 1.40 & 1.86 & 0.64 & 0.26 & 1.04 & $46 \%$ \\
\hline & 6-Month & Control & 4 & 170 & 2.50 & 2.50 & 2.00 & 1.75 & 2.19 & \\
\hline & Post-Removal & Net Area & 4 & 183 & 1.00 & 1.25 & 1.75 & 1.50 & 1.38 & \\
\hline & & Difference & & & 1.50 & 1.25 & 0.25 & 0.25 & 0.81 & $37 \%$ \\
\hline & 1-Year & Control & 5 & 238 & 2.80 & 2.60 & 2.40 & 2.20 & 2.50 & \\
\hline & Post-Removal & Net Area & 5 & 236 & 2.60 & 2.60 & 2.40 & 2.00 & 2.40 & \\
\hline & & Difference & & & 0.20 & 0.00 & 0.00 & 0.20 & 0.10 & $4 \%$ \\
\hline \multirow[t]{9}{*}{3} & Immediate & Control & 5 & 152 & 3.00 & 2.60 & 2.40 & 2.40 & 2.60 & \\
\hline & Post-Removal & Net Area & 5 & 180 & 1.20 & 1.60 & 1.60 & 2.00 & 1.60 & \\
\hline & & Difference & & & 1.80 & 1.00 & 0.80 & 0.40 & 1.00 & $38 \%$ \\
\hline & 6-Month & Control & 6 & 230 & 2.83 & 2.67 & 2.33 & 2.33 & 2.54 & \\
\hline & Post-Removal & Net Area & 5 & 242 & 1.60 & 1.80 & 2.20 & 2.00 & 1.90 & \\
\hline & & Difference & & & 1.23 & 0.87 & 0.13 & 0.33 & 0.64 & $25 \%$ \\
\hline & 1-Year & Control & 4 & 207 & 3.00 & 2.75 & 3.00 & 2.75 & 2.88 & \\
\hline & Post-Removal & Net Area & 7 & 267 & 2.71 & 2.86 & 2.57 & 2.71 & 2.71 & \\
\hline & & Difference & & & 0.29 & -0.11 & 0.43 & 0.04 & 0.17 & $6 \%$ \\
\hline \multirow[t]{9}{*}{4} & Immediate & Control & 6 & 265 & 3.00 & 2.33 & 1.67 & 1.50 & 2.13 & \\
\hline & Post-Removal & Net Area & 6 & 206 & 1.33 & 1.33 & 1.33 & 1.17 & 1.29 & \\
\hline & & Difference & & & 1.67 & 1.00 & 0.33 & 0.33 & 0.84 & $39 \%$ \\
\hline & 6-Month & Control & 6 & 237 & 2.83 & 2.83 & 1.83 & 1.67 & 2.29 & \\
\hline & Post-Removal & Net Area & 6 & 248 & 1.50 & 1.67 & 1.83 & 1.50 & 1.63 & \\
\hline & & Difference & & & 1.33 & 1.17 & 0.00 & 0.17 & 0.66 & $29 \%$ \\
\hline & 1-Year & Control & 6 & 273 & 3.00 & 2.67 & 2.67 & 2.33 & 2.67 & \\
\hline & Post-Removal & Net Area & 5 & 231 & 2.60 & 2.80 & 2.60 & 2.40 & 2.60 & \\
\hline & & Difference & & & 0.40 & -0.13 & 0.07 & -0.07 & 0.07 & $3 \%$ \\
\hline \multirow[t]{9}{*}{ All } & Immediate & Control & 22 & 966 & 2.77 & 2.51 & 2.11 & 1.64 & 2.26 & \\
\hline & Post-Removal & Net Area & 21 & 837 & 1.24 & 1.23 & 1.42 & 1.46 & 1.34 & \\
\hline & & Difference & & & 1.53 & 1.28 & 0.69 & 0.19 & 0.92 & $41 \%$ \\
\hline & 6-Month & Control & 19 & 744 & 2.46 & 2.50 & 2.21 & 1.85 & 2.26 & \\
\hline & Post-Removal & Net Area & 20 & 794 & 1.28 & 1.48 & 1.85 & 1.60 & 1.55 & \\
\hline & & Difference & & & 1.18 & 1.02 & 0.36 & 0.25 & 0.70 & $31 \%$ \\
\hline & 1-Year & Control & 21 & 929 & 2.87 & 2.67 & 2.64 & 2.36 & 2.64 & \\
\hline & Post-Removal & Net Area & 22 & 908 & 2.58 & 2.71 & 2.39 & 2.18 & 2.47 & \\
\hline & & Difference & & & 0.29 & -0.04 & 0.25 & 0.18 & 0.17 & $6 \%$ \\
\hline
\end{tabular}

Marine Habitat Recovery of Five Derelict Fishing Gear Removal Sites in Puget Sound, WA February 11, 2009

Page 12 
Approximately six months after net removal, the average relative abundance index for the four species groups over the four monitoring site was identical to the immediate post-net removal period for the unaffected control area with an average score of 2.26 (range 2.0 to 2.54 ) but increased about $15 \%$ for the net affected area from 1.34 (range 1.21 to 1.60 ) immediately after net removal to 1.55 (range 1.30 to 1.90) (Table 3). Average overall percent difference in relative abundant among the four species groups between net affected areas and control areas decreased somewhat but still ranged from 25\% at LTM\#3 to $37 \%$ at LTM\#2 and averaged $31 \%$ over all four monitoring sites.

Approximately one year after net removal, the average relative abundance index for the four species groups over the four monitoring sites was 2.64 (range 2.50 to 2.88) for the unaffected areas up $17 \%$ from the 2.26 relative abundance indices scored immediately after net removal and six months after net removal (Table 3). The average relative abundance index for the net affected area averaged 2.47 (range 2.15 to 2.71) an increase of $59 \%$ over the 1.55 value at six months after net removal and 97\% over the 1.34 value immediately after net removal. The largest increases in relative abundance indices in the net affected area among the four species groups occurred in the kelp/seaweed/hydroid $(101 \%)$ and sessile invertebrate species groups (83\%) between the six-month sampling period and the one-year sampling period. Average overall percent differences in relative abundance among the four monitoring sites and four species groups between the net affected areas and unaffected areas decreased to an average of $6 \%$ with a range of $3 \%$ at LTM\#4 to $14 \%$ at LTM\#1.

\section{Affected Versus Unaffected Area Video Review}

A total of 94 video clips totaling 59 minutes and 32 seconds were reviewed. The reviewer was aware of the monitor sites but not the monitoring time period or the source location of the video clip. The reviewer was allowed to review each clip once and then make an assessment of whether the clip was taken in a net affected area or in an unaffected control area.

For video clips recorded immediately after net removal, the reviewer correctly identified $30(88 \%)$ and incorrectly identified the location of four $(12 \%)$ out of 34 video clips reviewed (Table 4). For LTM\#3 and LTM\#4, the reviewer correctly identified the location of all of the video clips. The reviewer incorrectly identified the location of two out of eight video clips at LTM\#1 and two out of 10 video clips at LTM\#2. Out of the four errors made, three errors occurred when the reviewer mistook unaffected control habitat for net affected habitat and only once when net affected habitat was mistaken for control habitat.

The reviewer correctly identified 23 (92\%) and incorrectly identified two (8\%) locations of 25 video clips taken approximately six months after net removal at the four monitoring sites (Table 4). For LTM\#1 and LTM\#2 the location was correctly identified on all of the video clips reviewed and there was one incorrect identification each on LTM\#3 and LTM\#4. In both errors video clips shot in the unaffected control areas were incorrectly identified as being from the net affected areas. 
Table 4: Number of correct and incorrect assessments of whether video clips were of net affected or adjacent control areas at four long-term habitat monitor sites immediately after derelict net removal, six months and one year. (Assessment codes $\mathrm{C}=$ control area, $\mathrm{NA}=$ net affected area).

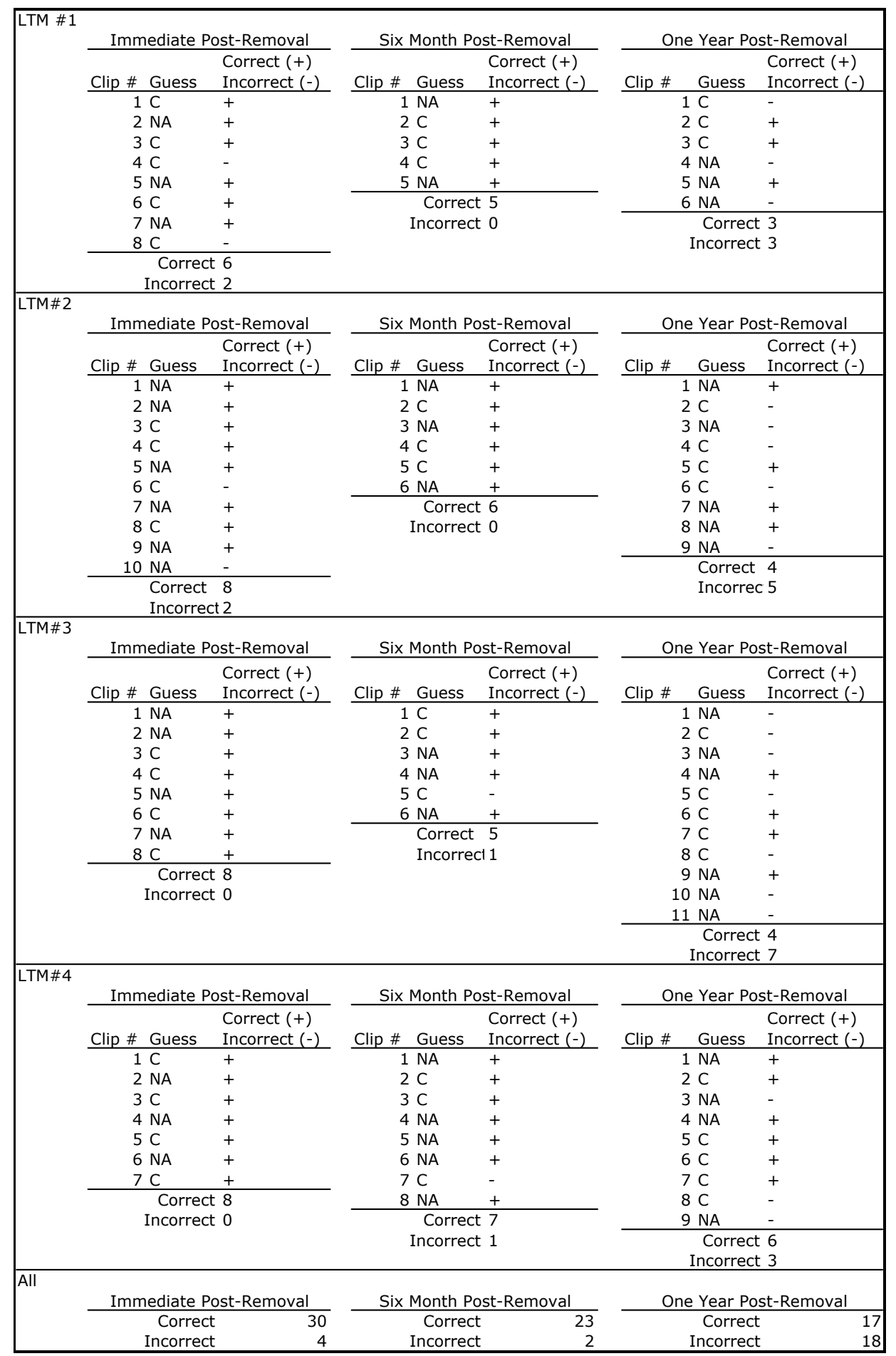

Marine Habitat Recovery of Five Derelict Fishing Gear Removal Sites in Puget Sound, WA

February 11, 2009

Page 14 
Of the 35 video clips reviewed from the four monitoring sites taken approximately one year after net removal the reviewer identified the location of 17 (49\%) video clips correctly and $18(51 \%)$ incorrectly. The reviewer incorrectly identified the majority of the video clip locations at LMT\#2 (five out of nine incorrect) and LTM\#3 (seven out eleven incorrect), had equal correct and incorrect location identifications (three out of six) at LTM\#1 and correctly identified the location of six out of nine video clips at LTM\#4. The reviewer indicated that many of the identifications were simple guesses and the video clips from the net affected and unaffected control areas were nearly impossible to differentiate.

Video tape review of LTM\# 5, the derelict crab pot location, supported the divers report of three-foot by five-foot scour area behind the pot. The scour area was obvious on the video tapes reviewed immediately after pot removal mainly due to lack of eelgrass and the darker color of the sediment. It was difficult to accurately estimate the degree of eelgrass recovery four and eight months after removal from video tape clips. The filling of the scour hole reported by the divers was not obvious from the video tape, although, the sediment color was uniform through both the pot affected and unaffected areas. Although it was not possible to compare counts of eelgrass plants from the three monitoring periods using the video tapes, both the pot location and the scour area appeared smaller in the video clips recorded four and eight months after pot removal. Diver counting eelgrass plants via a standardized grid inside and outside of the pot affected area during both monitoring periods would have been a preferable method to assess eelgrass habitat recovery.

Divers found no new derelict fishing gear at the four net monitoring sites or at the derelict crab monitoring site during the study.

\section{$\underline{\text { Conclusion }}$}

All three methods of assessing habitat recovery employed in the study (diver reports, video review of species abundance, and video clip review for net affected and control source location) provided corroborating evidence that marine habitats are negatively impacted by the presence and removal of derelict fishing gear but nearly complete habitat recovery probably occurs within one year or one marine growing season after derelict fishing gear removal (Figures 2 through 6). 


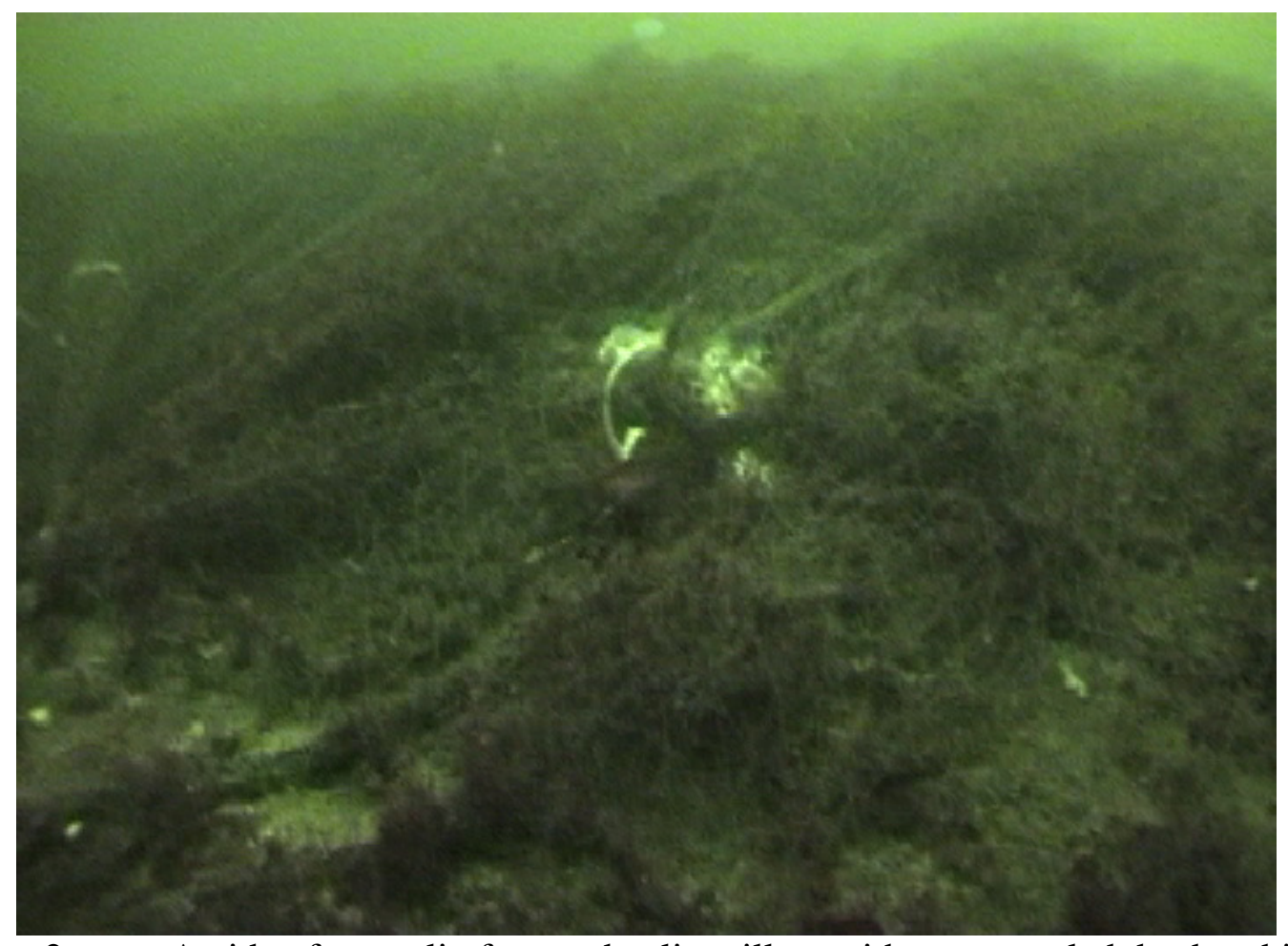

Figure 2: $\quad$ A video frame clip from a derelict gillnet with an entangled dead seabird on the seabed at Long-Term Monitoring site \#3 Eagle Point, San Juan Island.

Figure 3:

A video frame clip showing attached plants and animals on the seabed from an unaffected "control" area adjacent to the net affected area at Long-Term Monitoring site \#3 Eagle Point, San Juan Island.

Marine Habitat Recovery of Five Derelict Fishing Gear Removal Sites in Puget Sound, WA February 11, 2009

Page 16 


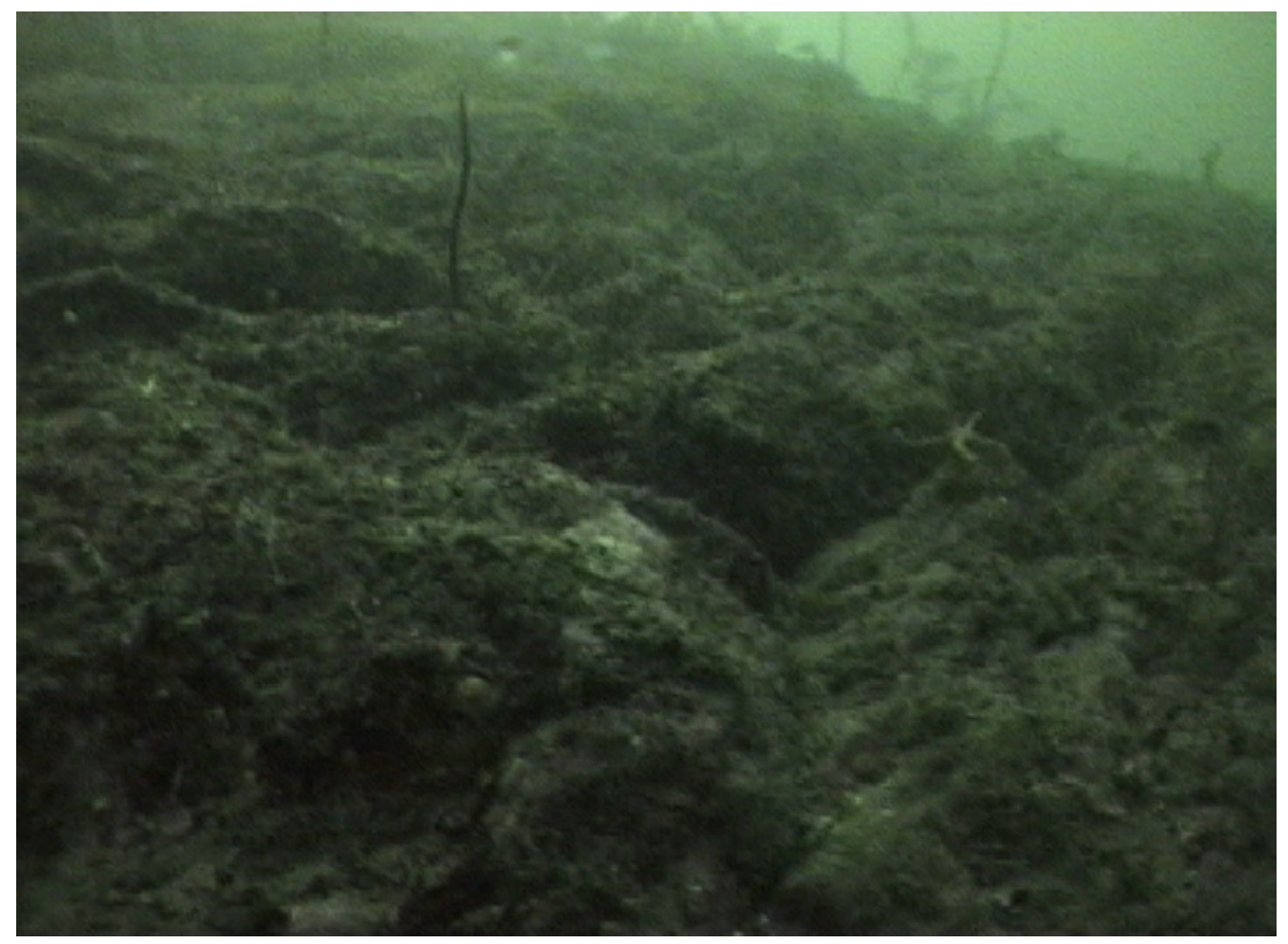

Figure 4. A video frame clip showing the net affected area immediately after derelict net removal at Long-Term Monitoring site \#3 Eagle Point, San Juan Island.

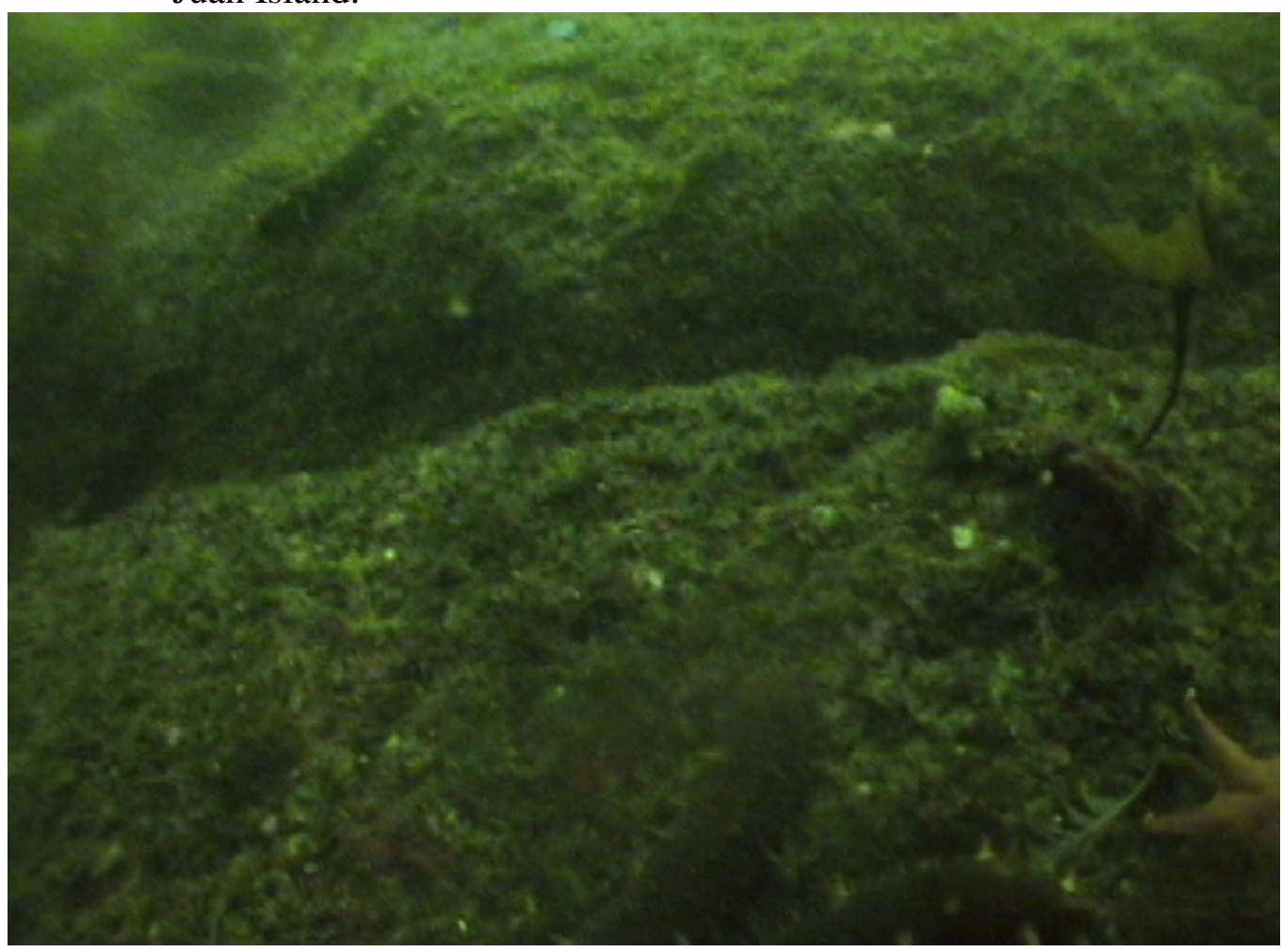

Figure 5. A video frame clip showing the net affected area approximately six months after derelict net removal at Long-Term Monitoring site \#3 Eagle Point, San Juan Island.

Marine Habitat Recovery of Five Derelict Fishing Gear Removal Sites in Puget Sound, WA February 11, 2009

Page 17 


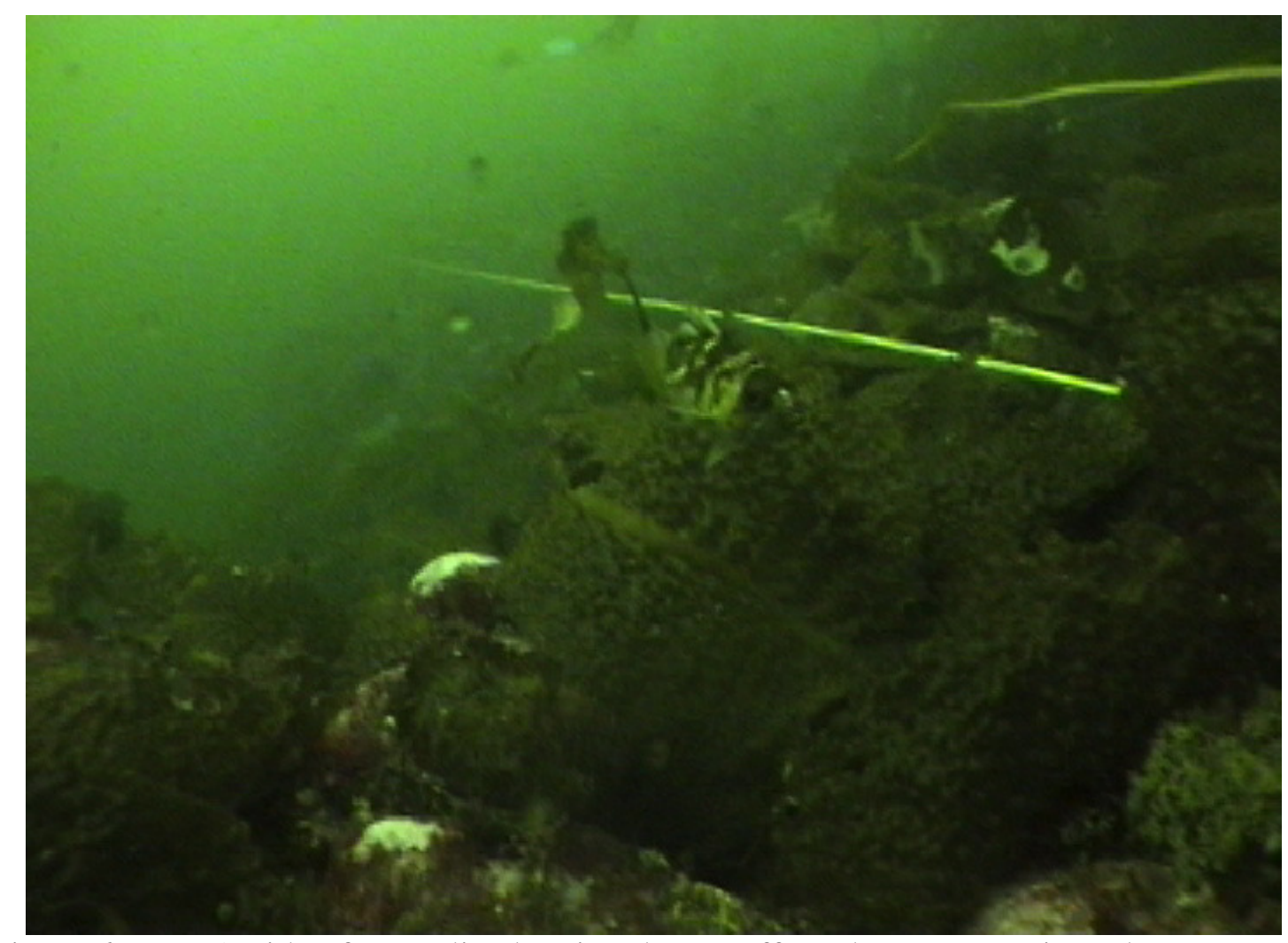

Figure 6. A video frame clip showing the net affected area approximately one year after derelict net removal at Long-Term Monitoring site \#3 Eagle Point, San Juan Island. (Note: yellow marker rope delineating net affected area in foreground).

The impacts of derelict fishing gear are many and varied depending upon the type of fishing gear lost and the type of habitat impacted. Derelict nets can cover marine habitats denying access to marine plants and animals. Derelict nets and leadlines can sweep the bottom or strum in place dislodging encrusting organisms and sessile animals. Exposed nets and operating crab pots can entangle or capture and kill target and non-target species. Divers report derelict nets accumulate soft sediments that suffocate underlying organisms. Derelict crab pots can impede eelgrass growth and currents around derelict pots can scour the seabed dislodging eelgrass in a far greater area than the pot footprint alone. Derelict gear induced negative habitat impacts probably result in reduced service functions from these habitats. Although some habitat damage likely occurs during derelict net removal operations as living plants and animals on the nets are dislodged or removed with the derelict gear, based on the results of this study, substantial habitat recovery probably occurs with one year of derelict gear removal.

Although changes in the service functions of the habitat were not directly measured in the study, changes in relative abundance of the four species groups assessed probably reflects changes in value of habitat service functions to these species over the habitat recovery period. Based on divers observations and reviews of underwater video, the difference between species abundance in the net affected areas and the unaffected adjacent control 
areas decreased from $41 \%$ immediately after net removal to $31 \%$ six months post-net removal to $6 \%$ one year after net removal.

Divers reported partial habitat recovery in shallow water eelgrass habitat four months after derelict crab pot removal. The current scour depression behind the pot had completely filled in with sediment, leveling the seabed with the surrounding habitat and eelgrass from the adjacent unaffected habitat had spread into the affected area decreasing the obvious pot impact area by about $30 \%$. The area surrounding the pot affected habitat had high eelgrass density. Little additional habitat improvement occurred eight months after pot removal over the fall and winter. Based on the partial recovery in the pot affected area after four and eight months, it is likely the pot affected area will make a full recovery after several growing seasons.

Seasonality may have had an influence on the timing of habitat recovery in the study. The derelict nets were removed between late June and late August 2007. The six month post-net removal monitoring was conducted in January and early February 2008 during winter when marine plant growth is minimal. The one year post-net removal monitor was conducted in September 2008, at the end of the summer when marine plants had a full season of growing opportunity in the net affected areas. It is possible that some habitat recovery from derelict fishing gear removal may occur in less than one year if removal operations are carried out prior to the start of the spring/summer growing season.

Divers found no additional lost fishing gear at any of the sites during the monitoring dives supporting fisher's and fishery managers' observations that many fewer nets are presently being lost in Puget Sound and San Juan Islands due to reductions in fishing effort and improvements in equipment and methods.

\section{$\underline{\text { Recommendations }}$}

Further research such as this would prove beneficial particularly if larger areas of habitat over several years were monitored. Considering the NWSI estimates there are thousands of derelict nets covering potentially thousands of acres of diverse habitats in Washington waters and thousands of derelict crab pots in shallow waters where eelgrass may be present, this study adds undeniable evidence of the importance of derelict fishing gear removal and subsequent natural habitat recovery. The absence of newly lost fishing gear during the project supports the hypothesis that most of the derelict fishing gear (particularly nets) problem in Washington State is a legacy issue from the 1950s through the 1980s when most of this gear was lost. With the reduction in net fishing effort, improvements in gear and methods and a no-fault lost gear reporting program in place, future net loss and impacts should be minimal and the removal of this historical derelict fishing gear will make an immediate and permanent improvement to the marine habitat in Washington State. 